УДК 37:004(07)

DOI: $10.15587 / 2519-4984.2019 .186200$

\title{
ОНТОЛОГІЧНІ ЗАСАДИ ФОРМАЛІЗАЦІЇ ІНФОРМАЦІЙНИХ ДЖЕРЕЛ У Е-ОСВІТНІХ СЕРЕДОВИЩАХ
}

\section{В. Б. Дем'яненко}

У статті наголошується на необхідності пошуку нових когнітивних парадигм, щяо містили б класифікації знань, концепцій, сутностей наукових категорій в освітньому середовищі, особливо у відкритому, комп'ютеро орієнтованому. Зазначається, щчо одним з перспективних напрямків подальшого вдосконалювання електронних систем навчання є розроблення методологічних і логічних основ конструювання освітніх систем на засадах комп'ютерних онтологій, на основі якого користувачеві надається цілісний, системний огляд певної предметної галузі - конщептуалізація певної галузі знань, щзо подається за допомогою визначення базових об'єктів $і$ зв'язків між ними. Визначено, щзо онтологічний підхід забезпечує ефективне проектування компонентів будь-якої знаннєво-орієнтованої інформаційної системи. Комп'ютерна онтологія в ирьму процесі виступає як діючий механізм створення відкритої освітньої системи, щуо відображає певну теорію, подану як множину термінів, зв 'язків між ними, пов'язаних описів та формальних аксіом, щзо сприяє інтерпретації та спільного використання циих термінів.

Описано технологію програмного комплексу ТОДАОС, щзо призначений для побудови освітніх локальних та мережевих (розподілених) систем на основі онтологій та контекстно-семантичного аналізу (від локальної онтолого-керованої системи забезпечення освітнього прочесу до системи інтегрованого багатофакторного аналізу освітніх інформаційних ресурсів за допомогою системи прийняття рішень та управління процесом формування знань) для забезпечення взаємодї усіх користувачів мережевих інформаційно-освітніх середовищ. Онтологічний підхід у наповненні адаптивних освітніх сервісів е-освітніх середовищ відображає понятійну систему певної дисииплінарної теорії, а методичне забезпечення навчально-пізнавального прочесу полягає у засвоєнні понятійної системи, аксіоматики, правил, синтаксичних та морфологічних основ иісї теорії

Ключові слова: е-середовище, класифікачія знань, комп'ютерна онтологія, онтологічний граф, трансдисциплінарні інформаційні ресурси

Copyright (C) 2019, V. Demianenko.

This is an open access article under the CC BY license (http://creativecommons.org/licenses/by/4.0).

\section{1. Вступ}

В умовах сучасності світова цивілізація переживає радикальні трансформації, зміни в багатьох фундаментальних цінностях суспільства. Це безпосереднім чином впливає на розуміння завдань і характеру освіти, система якої побудована на вимогах сучасності: збереження духовно-культурних цінностей людини і ствердження нових. Це важливо для визначення цільових установок освіти, іiі ціннісних основ i предметного змісту, міри доступності до неї кожного суб'єкту. В результаті відбувається формування суспільства 3 інтенсифікацією культурних зв'язків та обмінів, зростанням культурної різноманітності, відходом від домінуючої в епоху індустріального суспільства уніфікації та стандартизації формування особистості людини [1].

Настала ера, коли навчання триває все життя. В цих умовах посилюється потреба створювати й поширювати масиви даних у цифровому вигляді, навчати і підвищувати ефективність навчання шляхом колективної роботи в комп'ютерних мережах, використовувати технології глобальної мережі Internet. Розвиток системи освіти в нинішніх умовах визначається необхідністю безперервної, гнучкої, модульної, самостійної, випереджальної, розподіленої освіти, тобто реалізацією принципів відкритої освіти. Для нових форм освіти характерні інтерактивність і співпраця в процесі навчання, що можливо при створенні відкритих навчальних середовищ. Новим принципом освіти стає управління процесом формування знань формалізація створення баз знань. Світ став цифровим і його мешканці мають володіти цифровими технологіями та використовувати їх ефективно в різних галузях економіки, враховуючи і освіту та науку, i бізнес. В таких умовах ключовим моментом $є$ доступ до баз знань, що розміщуються у відповідних середовищах та можуть бути доступними для всіх учасників освітнього процесу (як для певної групи так і кожного окремо) з будь-якого місця та в будь-який час. В суспільстві, що грунтується на знаннях, центр уваги переноситься в сферу генерації знань. Забезпечення здобування цілісних знань, як пріоритет нових освітніх підходів повинен відновити гармонію зв'язків людини 3 природою, зменшити соціальну дезадаптацію сучасного учня. Тому сьогодення об'єктивно вимагає переведення освітнього процесу на технологічний рівень, активізації пошуку перспективних інноваційних й педагогічних технологій, спрямованих на розвиток і саморозвиток особистості. Використання цифрових технологій в цьому контексті допомагає значно підвищити ефективність здобуття та розуміння знань $[2,3]$.

\section{2. Літературний огляд}

Численні дослідження в галузі педагогіки засвідчують, що принциповими відмінностями сучас- 
ної освіти є перехід на рівневі системи, міждисциплінарний характер досліджень, ефективне співробітництво $з$ виробничим та науковим сектором, інтернаціоналізація наукової діяльності та формування міжнародних дослідницьких колективів, проведення стажування в закордонних наукових центрах, публікації результатів наукових досліджень у провідних наукових виданнях. Головний вектор досліджень спрямований на створення ефективних, відкритих е-освітніх систем (що засновані на використанні інформаційнокомунікаційних технологій), на структурування й подання наукових інформаційних джерел предметних галузей, формалізацію етапів побудови е-освітніх середовищ. Основні підходи, принципи, завдання i вимоги в побудові таких середовищ достатньо розроблені і успішно використовуються на всіх рівнях освіти [4].

Сучасне інформаційне суспільство характеризується мережеорієнтованою взаємодією між усіма його інституціями та системними складовими. Всесвітня мережа стала саме тим середовищем, де розгортається когнітивно-комунікативний сценарій розвитку освіти. Центральною їі ланкою є технології інженерії знань, які грунтуються на використанні ITBigData, Semantic-WEB та Data Mining, що надає можливість забезпечити усі процеси здобування знань в освітньому середовищі $[5,6]$. Тому успішність даного напрямку багато в чому визначається інтелектуальним рівнем i загальною ефективністю взаємозв'язків між мережними інформаційно-освітніми системами.

Використання мережевих інструментів та сервісів інформаційно-комунікаційних технологій в освітньому процесі дозволяє підвищити ефективність навчання, а також сприяє розвитку пізнавального інтересу учнів до здійснення навчально-дослідницької діяльності, формує позитивну мотивацію до навчання. В значній кількості педагогічних досліджень зазначається, що використання сучасних когнітивних інформаційно-комунікаційних технологій має значний потенціал у забезпеченні доступу до освіти та вдосконалення іiї якості [7].

Теоретичний аналіз сучасних психологопедагогічних досліджень щодо впровадження інформаційних процесів в освіту засвідчує, що створення електронних середовищ ефективної взаємодії усіх учасників навчально-виховного процесу (від учнів, вчителів, батьків, експертів-методистів до управлінців) можливе за умови використання електронних підручників, репозиторіїв цифрових освітніх ресурсів, віртуальних лабораторій, мультимедійних засобів навчання, рейтингових систем оцінювання навчальних досягнень учнів тощо [8, 9]. Крім того, вказані засоби сприяють розвитку критичного мислення та рефлексії учнівської молоді, оскільки учень залучається до моделювання об'єкта вивчення та може спостерігати й оцінювати результати своїх дій $[10,11]$. Але разом з тим, наразі наголошується на необхідності пошуку нових когнітивних парадигм, що містили б класифікації знань, концепцій, сутностей наукових категорій у зв'язку з процесами, що відбуваються в навчальному середовищі, особливо у відкритому, комп'ютеро орієнтованому. Відображення процесів реального світу потребує забезпечення спільного опрацювання значних об'ємів інформаційних джерел, складних процесів опрацювання взаємозв'язаних різнопланових інформаційних процесів, їх інтеграції й взаємозв'язків 3 іншими відмінними за призначенням системами. Тобто для відображення необхідно побудувати певну систему знань, яка описує властивості складових об'єктів та процесів, які нас оточують. Головна задача при цьому полягає в знаходженні (за потрібною тематикою), опрацювання та суттєвий аналіз величезних інформаційних джерел за допомогою мережевих інструментів, що дозволяє визначати властивості об'єктів задач та логічні закономірності між описаними поняттями. На наше бачення, одним 3 шляхів розв'язування зазначених проблем може бути використана комп'ютерна онтологія, як концептуалізація певної галузі знань.

\section{3. Мета та задачі дослідження}

Мета дослідження - обгрунтувати і описати технологію формалізації інформаційних джерел у еосвітніх середовища систем засобами програмного комплексу ТОДАОС.

Для досягнення мети були поставлені такі задачі:

1. Проаналізувати проблеми і наявний стан відкритих е-освітніх систем, персоналізованих еосвітніх середовищ.

2. Розглянути функції мережевих IКT засобів i сервісів та розкрити їх значення у формуванні та структуруванні інформаційних джерел у е-освітніх середовищах.

3. Розкрити та обгрунтувати онтологічний підхід для структуризації та формалізації інформаційних джерел у е-освітніх середовищах.

\section{4. Матеріали і методи}

Одним 3 перспективних напрямків подальшого вдосконалювання електронних систем навчання $\epsilon$ розроблення методологічних і логічних основ конструювання систем освіти на засадах комп'ютерних онтологій. При розробленні систем управління інформаційними джерелами проблематична задача не програмний аспект, а завдання пошуку, формулювання, формування, структурування та подання даних i повідомлень 3 яких в подальшому формуються знання. ІКТ-система - як складова відкритих систем освіти, що забезпечує ефективну реалізацію ІКТпроцесів, у якій збирання та опрацювання даних здійснюється автоматизовано за допомогою відповідних засобів комп'ютерної техніки та інформаційних технологій. Засоби і технології ІКТ-системи утворюють у відкритих системах освіти гнучке й адаптивне інтегроване організаційно-технологічне та інформаційно-обчислювальне середовище, що визначально впливає на формування найбільш сприятливих (інформаційно-комфортних) умов для ефективного здійснення іiі функцій [2]. При цьому зростають вимоги до підвищення продуктивності IКТ, їх надійності при постійному збільшенні обсягів опрацьованих даних. Однією із задач діяльності в таких середовищах $\epsilon$ надання умов ефективного використання інформаційних ресурсів усіма учасниками навчально- 
виховного процесу - учнями, викладачами, експертами, методистами та іншими фахівцями, залучення учнів до наукових досліджень, підготовки до участі в конкурсах, олімпіадах та вступу до вищих навчальних закладів. Для цього створюються засоби формалізації освітніх інформаційних джерел формування знань, що враховують специфіку навчальновиховного процесу різних типів навчальних закладів. При цьому головним аспектом $є$ наповнення педагогічно доцільним та методично виваженим предметним змістом $[12,13]$. За допомогою програмноінформаційних компонентів ІКТ забезпечується створення та використання баз навчальних та наукових джерел, на основі яких реалізується освітній процес для конкретної особистості учня. При використанні програмно-інформаційних засобів IКТ в навчально-дослідницькій діяльності учнів враховується той факт, що обсяг і розмаїтість даних та повідомлень, за різним профілем знань, нині, настільки об'ємний, що виникає необхідність їх класифікації $з$ погляду належності до предметних галузей або сфер інтересів всіх учасників навчально-дослідницької діяльності. І мова йде не тільки про дані, що зберігаються в спеціалізованих базах або інформаційних сховищах, але й про динамічні повідомлення, які генеруються певними джерелами в міру потреби. При формуванні персоналізованої системи освіти кожного учня необхідно накопичувати не розрізнені дані, а структуровані, формалізовані інформаційні джерела - закономірності й принципи, що дозволяють ефективно виконувати поставлені перед ним завдання. Це значною мірою стає можливим завдяки появі нових мережевих комп'ютеризованих засобів навчально-пізнавальної діяльності, відкритих комп'ютерно орієнтованих інформаційно-освітніх платформ підтримки навчання [14]. В них, через мережу Internet забезпечується комп'ютерна підтримка діяльності, реалізуються користувацькі i внутрішньомережеві сервіси. Користувацькі сервіси призначені для забезпечення гнучкого доступу до наявних в мережі науково-освітніх інформаційних ресурсів широкому (теоретично необмеженому) колу його потенційних користувачів. У свою чергу, функції внутрішньомережевих сервісів спрямовані на забезпечення збирання, накопичення, оновлення і зберігання різноманітних інформаційних джерел, формування, структурування i реорганізацію їх складу, а також здійснення внутрішньомережевих комунікацій та їх захисту від несанкціонованого доступу. На платформі такого середовища для кожного учня та вчителя створюються відповідні персоналізовані електронні площадки. Персоналізована електронна площадка (Network Platform) - віртуальний ІКТ-об'єкт адаптивних інформаційно-комунікаційних мереж, ситуаційна складова логічної мережної інфраструктури із тимчасовою гнучкою архітектурою, що за своєю будовою і часом існування відповідає персоналізованим потребам користувача, а його формування і використання базується на адаптивних технологіях [5].

5. Результати дослідження та їх обговорення Одним $з$ підходів для структуризації та формалізації інформаційних джерел у е-освітніх середови- щах, що може використовуватися онтологічний підхід, на основі якого користувачеві надається цілісний, системний огляд певної предметної галузі концептуалізація певної галузі знань, що подається за допомогою визначення базових об'єктів і зв'язків між ними. При цьому визначаються загальноприйняті, семантично значущі «понятійні одиниці» інформаційних ресурсів, якими оперують учні; візуалізуються результати процесів інтеграції та агрегації розподілених інформаційних джерел і ресурсів у процесі реалізації навчальних завдань у легкодоступній наочній формі. В комп'ютерних науках поняття «онтологія» трактується як формальне представлення знань набором концептів у межах домену та взаємозв'язків між цими концептами і використовується для опису властивостей концепту. Теоретично, онтологія - це формальна, явна конкретизація спільної концептуалізації. Онтологія пропонує спільну лексику, яка може бути використана для моделювання домену, тобто типу об'єктів та / або існуючих понять та їх властивостей та відношень [15]. Комп'ютерну онтологію предметної дисципліни можна розглядати як відкриту базу знань, що подана загальноприйнятою (формальною) мовою специфікації. В онтологокласифікаційній схемі засобів і методів штучного інтелекту онтологічний підхід трактується як різновид системного підходу, заснованого на знаннях. Онтологічний підхід забезпечує ефективне проектування компонентів будь-якої знаннєво-орієнтованої інформаційної системи. Комп'ютерна онтологія в цьому процесі виступає як діючий механізм створення відкритої системи освіти, що відображає певну теорію, подану як множину термінів, зв'язків між ними, пов'язаних описів та формальних аксіом, що сприяє інтерпретації та спільного використання цих термінів. Комп'ютерну онтологію можна розглядати як певну експліцитну концептуалізацію логічної теорії деякого числення 3 певними правилами, що дозволяє систематизувати категорії дійсності як такі, що подаються мовою значень, та які є у змісті предметної дисципліни. До того ж онтологічні методи та системи забезпечують концептуальне відображення взаємозв'язків мережних інформаційних процесів і систем в різних предметних галузях за рахунок системних компонентів:

a) множин концептів, як структури семантичних одиниць - понять;

б) формальної моделі предметного контенту, поданої за допомогою деякої мови на основі опису концептуальної системи;

в) функціональної моделі, яка забезпечує уніфікацію термінології, логіку опрацювання таксономічних категорій і зв'язків між ними, а також аксіоматизацію описів процесів, причинних зв'язків і процедур онтології.

Для розробки пропонуються онтології, в термінах яких розробники інтерфейсу формують відповідні компоненти його моделі; генерація інтерфейсу здійснюється кількома мовами програмування на різних платформах; підтримуються як локальна, так i мережна взаємодія; модель інтерфейсу розділена на компоненти відповідно до груп фахівців, що здійснюють його розробку (експертів предметної галузі, 
програмістів, дизайнерів) і містить всі дані, необхідні для його розробки і автоматичної генерації згідно моделі. Таким чином, модель інтерфейсу складається 3 наступних компонентів:

а) моделі системи понять діалогу (описується система термінів предметної галузі, в яких подаються вхідні/вихідні дані, методика використання інтерфейсу користувачем, а також інтелектуальної підтримки дій користувача);

b) моделі задач користувача (описуються завдання, які він може виконати, використовуючи програмну систему);

с) моделі подання (описується структура i властивості візуального подання елементів інтерфейсу);

d) моделі сценарію діалогу (визначається безліч можливих станів діалогу і дій, які виконуються);

е) моделі зв'язку інтерфейсів системи освіти 3 програмними.

Зазначені моделі реалізовано в програмному комплексі ТОДАОС, розробленого науковцями Національного Центру «Мала академія наук України» для створення відкритих е-освітніх систем. ТОДАОС (Трансдисциплінарні Освітні Діалоги
Аплікаційних Онтологічних Систем) - технологія для побудови освітніх навчально-дослідницьких, локальних та мережевих (розподілених) систем на основі онтологій та контекстно-семантичного аналізу (від локальної онтолого-керованої системи забезпечення навчального процесу до системи інтегрованого багатофакторного аналізу освітніх інформаційних ресурсів за допомогою онтологічної системи прийняття рішень та управління процесом формування знань) для забезпечення взаємодії усіх користувачів мережних інформаційноосвітніх середовищ [16, 17]. Трансдисциплінарність онтологічної системи - часткова упорядкованість множин таксономічних та операціональних властивостей онтологічних (концептуальних) моделей предметних галузей. Візуальні методи проектування онтологій сприяють швидшому і повнішому розумінню структури знань предметної галузі. Реалізація технології онтологічної інтеграції розподілених інформаційних ресурсів відбувається шляхом побудови онтологічного графа (рис. 1), вершинами якого є поняття, об'єкти і процеси предметних галузей (концепти) та візуалізація його в об'єктному відображенні (рис. 2) та у вигляді структурованої бази знань (рис. 3).

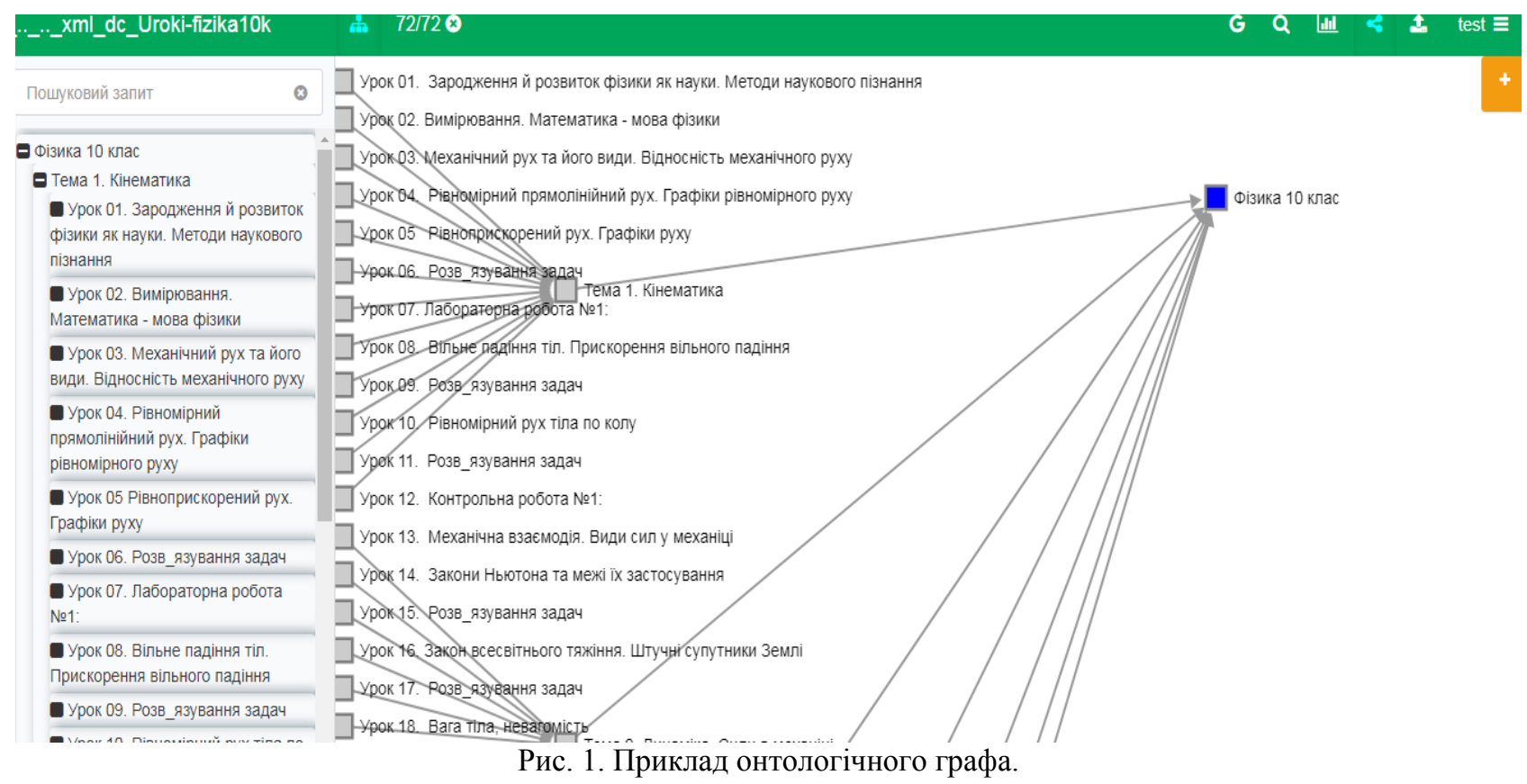

Режим відображення онтографа призначений для одночасного відображення значної кількості об'єктів і зв'язків між ними.

Режим об'єктного відображення представляє об'єкти онтології у вигляді списків, розбитих за рівнями.
Верхній рівень містить кореневі категорії, а також об'єкти без категорій. Користувач може обрати категорію, натиснувши на неї, така категорія стане актуалізованою, і на їі основі сформується наступний рівень - першим елементом рівня буде сама актуалізована категорія, а іншими елементами - всі їі підкатегорії і дочірні об'єкти. 


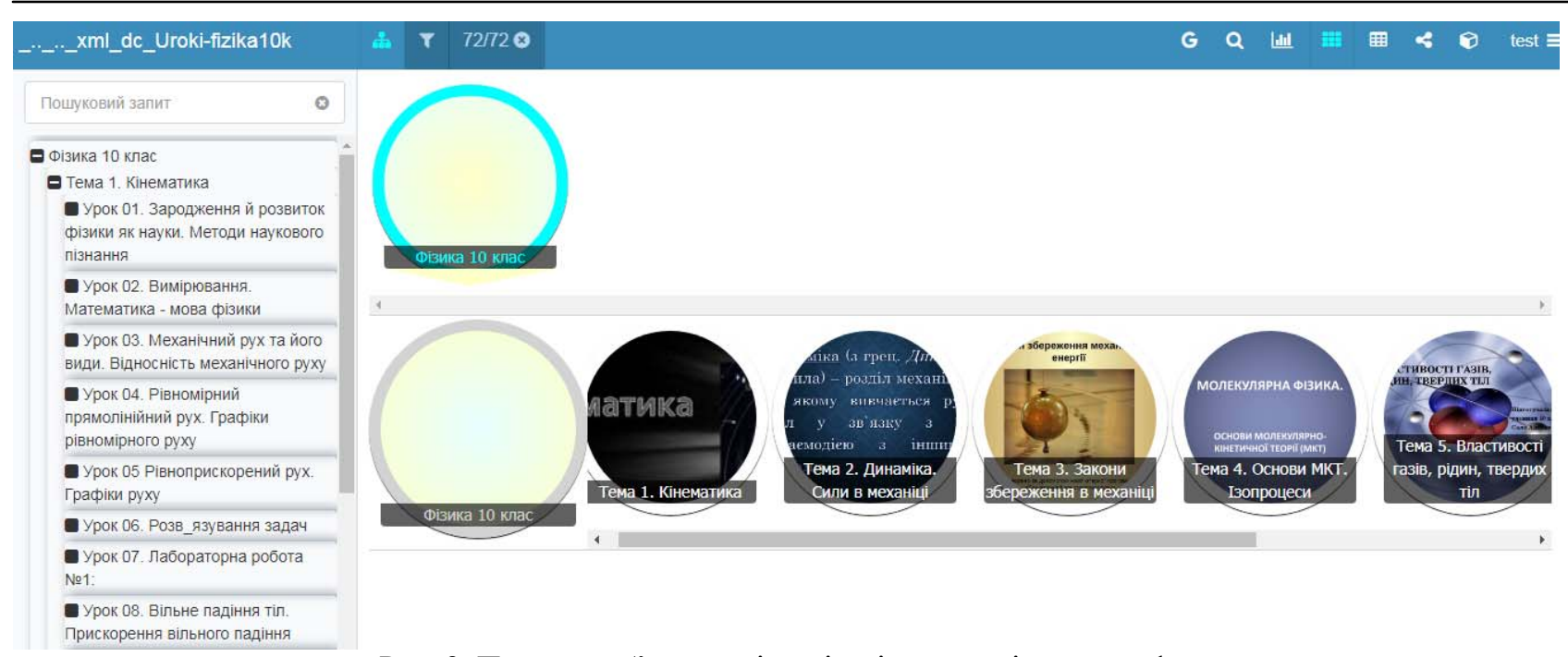

Рис. 2. Приклад об’єктної візуалізації онтологічного графа.

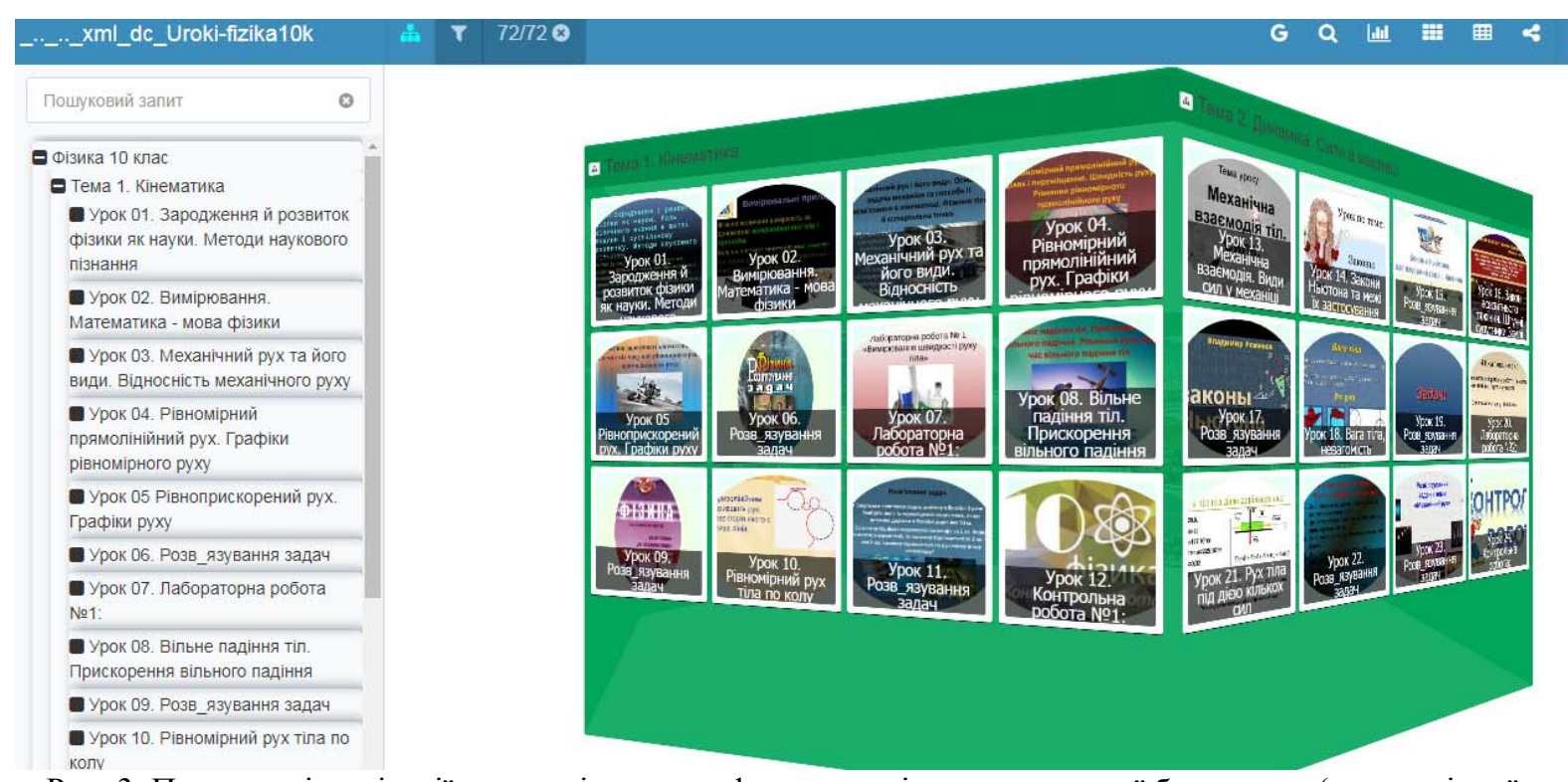

Рис. 3. Приклад візуалізації онтологічного графа у вигляді структурованої бази знань (онтологічної призми)

Режим онтологічної призми - призначений для відображення деревовидних структур даних. Даний режим використовує три рівня, аналогічно до тих, що використовуються в об'єктному відображенні.

1. Перший рівень складає коренева категорія онтології. Якщо таких категорій кілька, то використовується перша 3 них. Така категорія представляє всю призму і явно не відображається в робочій області.

2. Другий рівень складають підкатегорії кореневої категорії. Вони формують грані призми, а імена цих категорії відображаються в верхній частині відповідної грані.

3. Третій рівень формується підкатегоріями i дочірніми об'єктами категорій другого рівня. Такі об'єкти представляються блоками на відповідних гранях - аналогічно до об'єктного представлення. Максимальна кількість блоків на грані - 25, якщо дочірніх об'єктів в категорії більше, то вони розбиваються на сторінки, а в заголовку грані відображаються перемикач сторінок.
Програмний комплекс ТОДАОС є мережевим та кросплатформеним. Для роботи з ТОДАОС користувачу потрібні базові знання при роботі з операційною системою Windows: вміння запускати програми, працювати з вікнами та стандартними елементами вікон (меню, закладками, кнопками, випадаючими списками, полями внесення даних тощо); основами роботи із мережею Internet: вміння переходити до web-сторінок, користуватись стандартними функціями (завантажити файл, зчитати, видалити тощо), мати найпростіші навички роботи 3 пошуковими web-системами а також вміння працювати 3 текстовим редактором MS Word та табличним процесором MS Excel.

Функціонально систему ТОДАОС складають такі підсистеми.

КОНСПЕКТ (Text Termin) призначена для:

- побудови термінологічних дерев на основі аналізу природно-мовного тексту;

- лінгвістичного аналізу тексту до рівня спрощеного синтактичного та семантичного аналізів; 
- виокремлення термінів предметної галузі 3 релевантних текстів;

- виокремлення і стисле конспектування фрагментів природно-мовних текстів, що стосуються заданої теми, яка задається ключовим словом або словосполученням;

- генерація за наслідками семантичного аналізу заданого числа вторинних ключів, використання яких в циклічному режимі дозволяє поглибити розкриття теми в сформованих конспектах;

- використання стислих тематичних конспектів для добору множини текстових документів, що найбільшою мірою релевантні заданій темі.

ЕДИТОР (Graph Editor) призначена для формування онтологічних моделей. Вершинами графів $\epsilon$ певні концепти. Через ребра графа визначаються зв'язки між поняттями та класами концептів.

ПОШУКОВА МАШИНА призначена для пошуку лексичних структур на основі лінгвістичного опрацювання великої кількості текстових масивів.

WEВ-CЕРВІC IНДЕКСАТОР MINDEXER призначена для індексації сайту, сторінок цього сайту спеціальним програмою, з подальшим занесенням даних про них в базу пошукової системи.

Використання онтологічних моделей щодо формалізації інформаційних джерел у е-освітніх середовищах з формуванням бази предметних галузей дозволяє розширити їі функціональні характеристики та забезпечити реалізацію механізмів семантичного пошуку інформаційних джерел, як в самому середовищі так і в мережі Інтернет.

Визначено чотири основні компоненти моделі онтологічного інтерфейсу предметної галузі і, відповідно, чотири класи систем понять:

1) система понять користувача, в термінах якої він використовує прикладну програму. У цій системі понять зазначаються вхідні і вихідні дані прикладної програми, а також дані про інтелектуальну підтримку дій користувача;

2) система понять подання інформаційних джерел, в термінах якої визначаються різні типи діалогу. Даний клас містить три типи систем понять: систему понять графічного інтерфейсу користувача; систему понять графічних статичних сцен; систему понять формування текстів. Таким чином, кожна 3 систем понять підтримує проектування одного 3 типів діалогу;

3) система понять для визначення сценаріїв діалогу. Визначаються абстрактні терміни для опису реакцій на події (набори дій, які виконуються при виникненні подій, джерела подій, види режимів переходів між вікнами, способи вибору примірників вікон та ін.);

4) система понять зв'язків, в термінах якої здійснюється зв'язок між прикладною програмою i інтерфейсом відкритої системи освіти. Вона визначає змінні, типи їх значень, які є загальними для інтерфейсу системи та прикладної програми, а також протоколи за допомогою яких відбувається комунікація, адреси серверів, за якими проводяться з'єднання, а також методи передавання повідомлень.

Інформаційні ресурси у відкритій системі освіти подані описами у вигляді природно-мовних конструк- цій, що відображають судження та твердження про певні факти предметно-тематичного профілю. Факти зв'язуються між собою множинами зв'язків, а також можуть характеризуватися певними властивостями.

За допомогою запропонованого підходу можуть бути виконані завдання відкритої е-освіти, а саме:

а) автоматизоване розроблення баз формування знань навчального призначення на основі лінгвосемантичного аналізу великих обсягів текстових даних з використанням оригінальних інструментальних засобів, водночас вихідні текстові дані можуть використовуватися з різних джерел;

b) структурування термінів і понять з визначеної предметної дисципліни, що містяться в інформаційних навчальних ресурсах;

c) істотне зменшення трудомісткості складання баз формування знань навчального призначення;

d) забезпечення багатоаспектного аналізу навчально-пізнавальної діяльності учнів;

е) забезпечення лінгвістичного опрацювання та аналізу мовних текстів за допомогою сучасних інструментів контекстно-семантичного аналізу;

f) забезпечення експериментальної та дослідницької діяльності в будь-яких галузях діяльності людини за рахунок використання інженерії знань;

g) розроблення державної розподіленої системи дистанційного навчання зі створенням авторизованих майданчиків персональної та колективної взаємодії;

h) забезпечення підвищення рівня знань та формування наукового світогляду дитини за рахунок використання трансдисциплінарних підходів в освіті;

i) підвищення рівня підготовки та перепідготовки педагогів та науковців.

\section{6. Висновки}

1. Проаналізовано наявний стан і проблеми відкритих е-освітніх систем, персоналізованих еосвітніх середовищ. 3'ясовано, що при загостренні проблем формування відкритих освітніх систем, новим принципом освіти стає управління процесом формування знань - формалізація створення баз знань. Це стає можливим завдяки появі нових комп'ютеризованих засобів навчально-пізнавальної діяльності, відкритих е-освітніх середовищ, що більш повно відповідають темпам мінливості та цілям сучасної освіти.

2. Розглянуто функції мережевих IКТ засобів і сервісів та розкрито їх значення у формуванні та структуруванні інформаційних джерел у е-освітніх середовищах. 3'ясовано, що користувацькі сервіси призначено для забезпечення гнучкого доступу до наявних у е-освітніх середовищах науково-освітніх інформаційних ресурсів широкому (теоретично необмеженому) колу його потенційних користувачів. Функції внутрішньо мережевих IКТ та сервісів спрямовано на забезпечення збирання, накопичення, оновлення та зберігання різних інформаційних матеріалів, формування, структурування та реорганізацію їх складу, а також здійснення внутрішньомережевих комунікацій та захисту інформаційних матеріалів від несанкціонованого доступу. 
3. Розкрито та обгрунтовано онтологічний підхід для структуризації та формалізації інформаційних джерел у е-освітніх середовищах. Онтологічний підхід у наповненні адаптивних освітніх сервісів еосвітніх середовищ відображає понятійну систему певної дисциплінарної теорії, а методичне забезпечення навчально-пізнавального процесу полягає у засвоєнні понятійної системи, аксіоматики, правил, синтаксичних та морфологічних основ цієї теорії. Це забезпечує формування операціонального простору діяльності учнів, у якому вони здатні взаємодіяти 3 іншими учасниками освітнього процесу на основі діяльнісного та компетентнісного підходів, знаходячись у різних станах розвитку цього простору. Більше того, від рівня засвоєння понятійних систем, дисциплін, що вивчаються залежить і спроможність учня компетентно використовувати адаптивні освітні сервіси, тобто наукові понятійні теорії предметних дисциплін, що $є$ знання-функціональним ядром навчально-пізнавального діяльнісного простору учня. У цьому просторі забезпечується інтеграція з компонентами навколишнього середовища, як на соціальному так і на тематичнодисциплінарному рівнях.

\section{Література}

1. Синергетика і творчість: монографія / ред. Кремень В. Г. Київ: Інститут обдарованої дитини, 2014. 314 с.

2. Дем'яненко В. Б., Дем'яненко В. М., Стрижак О. С. Відкрита освіта у викликах сьогодення // Навчання і виховання обдарованої дитини: теорія та практика. 2016. № 2 (17). С. 49-55.

3. Moser S., Zumbach J., Deibl I. The effect of metacognitive training and prompting on learning success in simulation-based physics learning // Science Education. 2017. Vol. 101, Issue 6. P. 944-967. doi: http://doi.org/10.1002/sce.21295

4. Биков В. Ю. Моделі організаційних систем відкритої освіти: монографія. Київ: Атіка, 2008. 684 с.

5. Дем'яненко В. Б., Дем'яненко В. М. Онтологічні аспекти освітніх сервісів адаптивного навчання // Наукові записки. Національний педагогічний університет імені М. П. Драгоманова. 2017. № 133. С. 68-78.

6. Algarni A. Data Mining in Education // International Journal of Advanced Computer Science and Applications. 2016. Vol. 7, Issue 6. P. 456-461. doi: http://doi.org/10.14569/ijacsa.2016.070659

7. Leach J. Do new information and communications technologies have a role to play in the achievement of education for all? // British Educational Research Journal. 2008. Vol. 34, Issue 6. P. 783-805. doi: http://doi.org/10.1080/01411920802041392

8. Brinson J. R. Learning outcome achievement in non-traditional (virtual and remote) versus traditional (hands-on) laboratories: A review of the empirical research // Computers \& Education. 2015. Vol. 87. P. 218-237. doi: http://doi.org/10.1016/ j.compedu.2015.07.003

9. Interactive simulations for science and math. University of Colorado Boulder, 2015. URL: https://phet.colorado.edu/

10. Дем'яненко В. Б. Онтологічна модель мережецентричного науково-освітнього середовища // Інноваційні технології навчання обдарованої молоді: мат. третьої міжнар. конф. Одеса, 2017. С. 22-26.

11. Pierson A. E., Clark D. B. Engaging students in computational modeling: The role of an external audience in shaping conceptual learning, model quality, and classroom discourse // Science Education. 2018. Vol. 102, Issue 6. P. 1336-1362. doi: http://doi.org/10.1002/sce.21476

12. Chandrasekaran A., Linderman K. Managing Knowledge Creation in High-Tech R\&D Projects: A Multimethod Study // Decision Sciences. 2015. Vol. 46, Issue 2. P. 267-300. doi: http://doi.org/10.1111/deci.12129

13. Schuck S., Aubusson P. Educational scenarios for digital futures // Learning, Media and Technology. 2010. Vol. 35 , Issue 3. P. 293-305. doi: http://doi.org/10.1080/17439884.2010.509351

14. Yalcin N., Altun Y., Kose U. Educational material development model for teaching computer network and system management // Computer Applications in Engineering Education. 2015. Vol. 23, Issue 4. P. 621-629. doi: http://doi.org/10.1002/cae.21636

15. Man D. Ontologies in computer science // Didactica mathematica. 2013. Vol. 31, Issue 1. P. 43-46.

16. Стрижак О. Є. Онтологічний підручник - парадигма формування інтерактивної системи знань у навчальному процесі // Комп’ютер у школі та сім’ї. 2016. № 7 (135). С. 7-16.

17. Стрижак О. С. Управління знаннями - головна парадигма сучасної освіти // Комп'ютер у школі та сім'ї. 2016. № 5 (133). C. 9-11.

Received date 25.09.2019

Accepted date 24.10.2019

Published date 30.11.2019

Дем'яненко Валентина Борисівна, кандидат педагогічних наук, завідувач відділу, відділ інформаційнодидактичного моделювання, Національний центр «Мала академія наук України», Кловський узвіз, 8, м. Київ, Україна, 01021

E-mail: valentyna.demianenko@gmail.com 